\title{
In Service to the Nation-The Geology Scientist Emeritus Program
}

\section{Introduction}

The Geology Scientist Emeritus Program of the U.S. Geological Survey was established in 1986 as part of the Bureau's Volunteer for Science Program. The purpose of the Scientist Emeritus (SE) Program is to help support retired USGS senior scientists as they volunteer their expertise, intellect, and creativity in efforts that allow them to remain active in the geoscience community, enhance the program activities of the Geology Discipline, and serve the public.

The SE Program is open to all scientists and technical experts who have demonstrated leadership qualities and contributed to the goals of the USGS during a productive career. As long as the individual applying has been a scientist or technical expert, he or she may be considered for the SE Program, regardless of their previous position with the USGS.

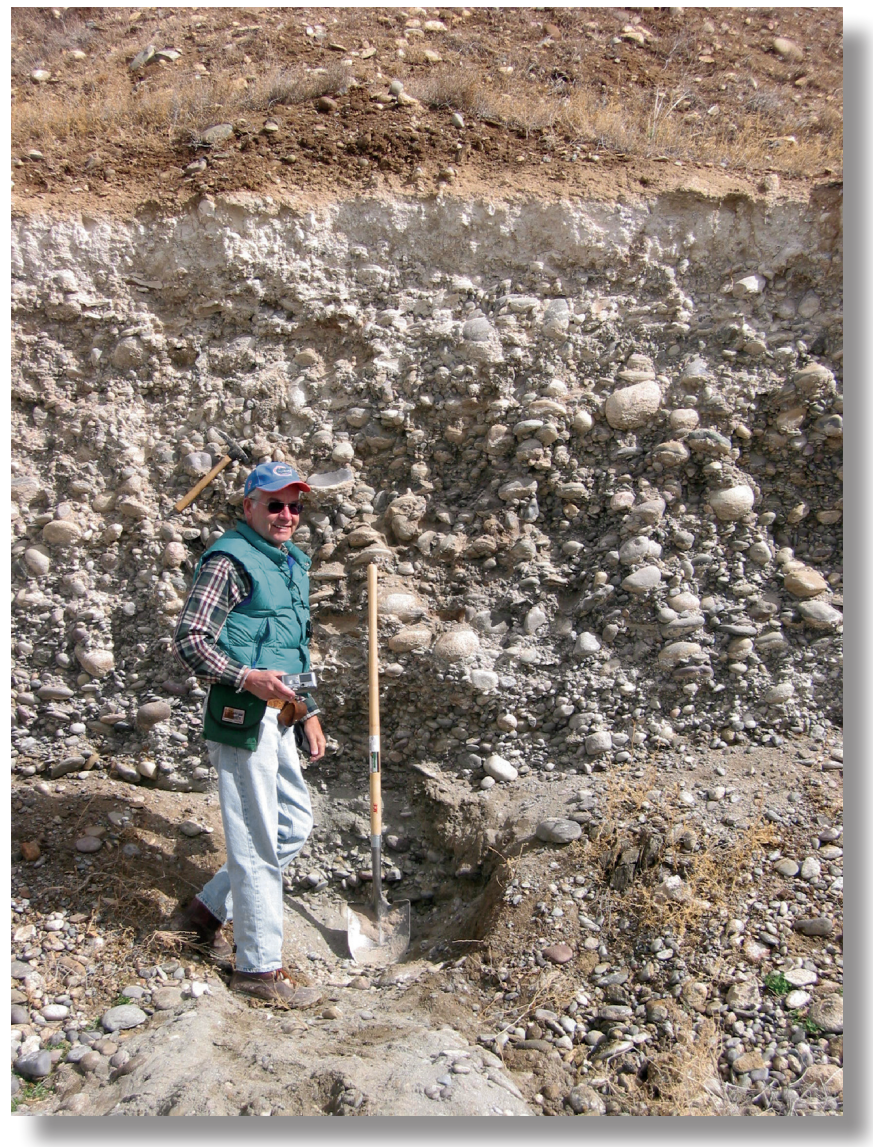

Scientist Emeritus, Dave Lindsey, helped a team from Central Region Mineral Resources Team study Wind River terrace gravel for construction aggregate in April 2005. The photograph shows middle Pleistocene gravel in a pit west of Riverton, Wyoming. The study was conducted for the Bureau of Indian Affairs and funded by the Bureau of Land Management.

\section{Bradley Scholar Program}

In 2007, the Geology Discipline reestablished and expanded the Bradley Scholar Program for its USGS Scientists Emeriti. This program, in honor of former USGS geologist Bill Bradley, provides as much as $\$ 5,000$ per year for up to 3 years for a Scientist Emeritus to conduct new research or to finish products that are near completion. In fiscal year 2007 (FY07) $\$ 100,000$ was awarded to $25 \mathrm{SEs} ; 61$ percent of the funds was allocated for completing legacy products, and 39 percent was for new research. Scientists Emeriti apply for funding, and the proposals are evaluated by a panel. The panel makes recommendations to the Associate Director for Geology, who makes the final decisions and allocates the money.

Twenty-five Scientists Emeriti received funds in 2007 for scientific endeavors that include completing geologic maps, writing general interest publications, studying volcanoes, supporting tsunami studies, investigating effects of a meteor impact, mineral deposit studies, paleontological studies, and laboratory data preservation. See the Scientist Emeritus Web site (http://geology.usgs.gov/Emeritus/) for a list of all the Bradley Scholar Program recipients and their projects.

\section{Dallas Peck Award Recipient}

\section{William Aubrey Cobban}

Bill Cobban first started with the USGS in 1948, and during his career he authored or coauthored more than 300 scientific papers. He is internationally recognized for his outstanding work on the marine Cretaceous fossils and rocks of the Western Interior of the United States. Bill retired in 1992, but his work has continued unabated, and he has produced approximately 50 publications since he retired. For example, in 2006, he completed the most comprehensive Upper Cretaceous ammonite and inoceramid biostratigraphy ever done. In 2006, a symposium on the "Paleontology, Geology, and Stratigraphy of the Late Cretaceous Western Interior Seaway" was held in honor of Bill.

\section{Regional Scientist Emeritus Best Publication Award}

Winners of this new award, which was established in 2006, include David Stewart and Robert Tilling for their contributions to the extraordinary map "This Dynamic Planet: World Map of Volcanoes, Earthquakes, Impact Craters, and Plate Tectonics" (U.S. Geological Survey Geologic Investigations Series Map I-2800). This product is the most widely distributed map in USGS history. Both Dave and Bob contributed an exceptional amount time, effort, and creativity to preparation and production of the map. 


\section{Scientist Emeritus Award Recipients}

\author{
Dallas Peck Award \\ 2007 - Rabert Schuster \\ 2006-William Lee. Peter Lipman, and William Cobban
}

\author{
Best Publication Awards \\ 2007 - Richard Meyer, Farrest Poole, Peter Barnes \\ 2006 - David Stewart and Rabert Tilling, John Reed, and \\ Dames Moore
}

For more information about the award recipients and their work, visit our Web site at http://geology.usgs.gov/Emeritus/.

\section{Benefits of the Scientist Emeritus Program}

The tangible and intangible benefits to the Geology Discipline and, ultimately, the USGS for this investment are numerous. Each year, approximately 200 Geology retirees continue their careers by returning to the organization in a volunteer status. These esteemed scientists and technical experts provide continued leadership and support to on-going projects, serve on outside scientific advisory panels and boards, act as senior advisors on USGS committees, and participate in numerous USGS outreach projects. Scientists Emeriti represent the USGS and speak at national meetings. They provide technical leadership to younger research and operational scientists. Scientists Emeriti secure data at risk and review papers on a broad range of topics. Numerous hours are spent mentoring junior research scientists and responding to inquiries from "Ask-A-Geologist". From 2000 to 2006, 74 Scientists Emeriti produced more than 550 publications (http://geology.usgs.gov/Emeritus/pubs.shtml).

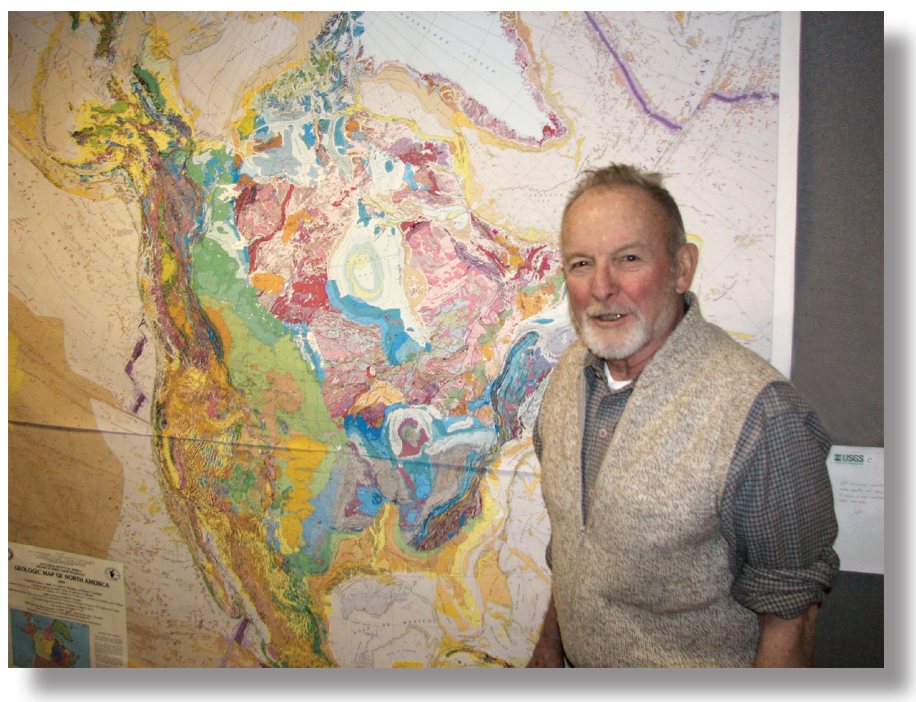

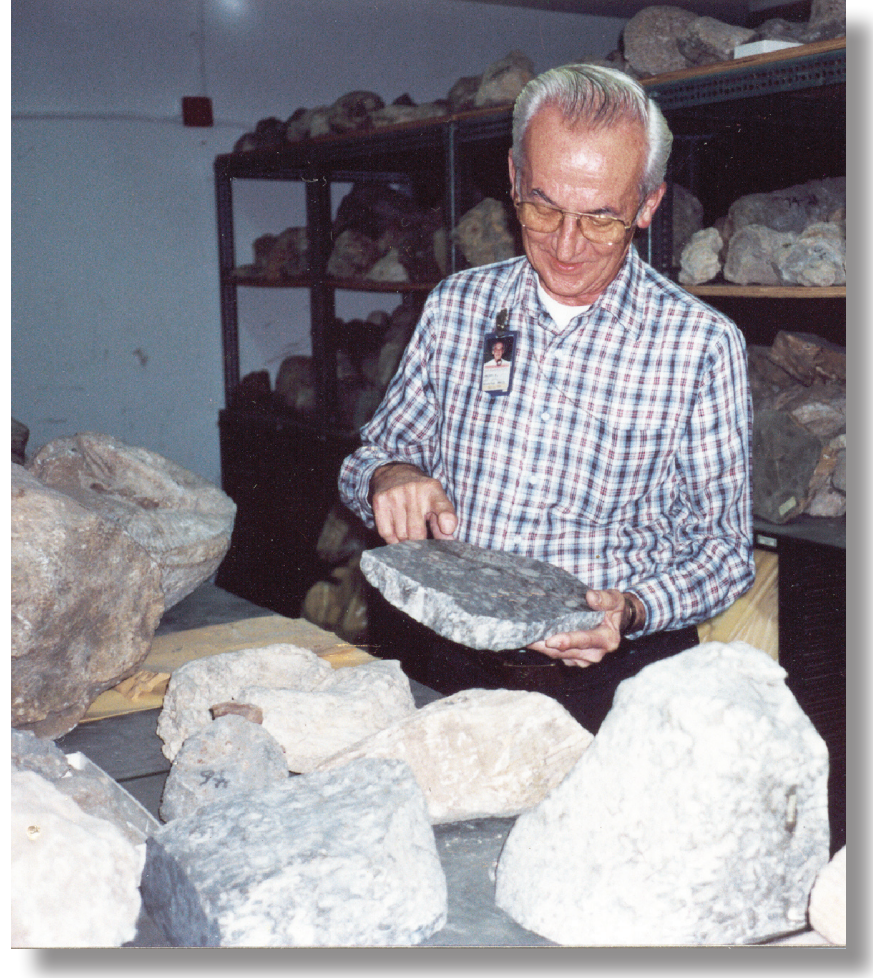

Scientist Emeritus John Pojeta, a specialist in Paleozoic mollusks, examines fossil slabs.

In 2005 and 2006, Geology invested approximately $\$ 201,000$ and $\$ 135,000$, respectively, for miscellaneous expenses incurred by Scientists Emeriti. Scientists Emeriti volunteered an estimated 112,250 hours in FY05 and 122,206 hours in FY06. If these were salaried hours (based on a GS-14/5 salary in Denver, Colo.), this would have cost the USGS \$5,724,750 in FY05 and \$6,232,506 in FY06. This is a significant cost benefit to the USGS.

\section{Summary}

The USGS Geology Scientist Emeritus Program and the reintroduced Bradley Scholar Program have allowed many retired USGS senior scientists and technical experts to continue to pursue their passion for science. Geology views the Scientist Emeritus Program, and all the benefits it provides, as a crown jewel of our organization.

For more information about the Scientist Emeritus Program as well as other award recipients visit our Web site at http://geology.usgs.gov/Emeritus/.
Scientist Emeritus John Reed received in 2006 one of three Best Publications Awards for his authorship of the "Geologic Map of North America." 